УДК 172.13

DOI https://doi.org/10.32837/apfs.v0i32.1030

\author{
М.О. Петренко \\ ORCID ID: https://orcid.org/0000-0003-2506-5305 \\ кандидат філософських наук,
} асистент кафедри філософії, культурології та інформаційної діяльності Східноєвропейського національного університету імені Володимира Даля

\title{
ФЕНОМЕН ВІДПОВІДАЛЬНОСТІ В СУЧАСНІЙ ЗАРУБІЖНІЙ ФІЛОСОФІЇ
}

Складний та суперечливий розвиток сучасного суспільства, широке використання результатів цифрової та четвертої промислової революцій, постійне збільшення населення створюють критичне навантаження на довкілля, екологію, людські взаємини та суспільні інституції. До того ж цифровізація, інформатизація та віртуалізація процесів управління об'єктами критичної інфраструктури збільшують відповідальність за належне виконання посадових обов'язків з огляду на катастрофічні наслідки їх недотримання. Подальша віртуалізація суспільного простору та суспільних відносин формують новий сучасний морально-етичний кодекс поведінки людини у кіберпросторі. Ось чому формування сучасного образу відповідальності починає все більше залежати не від техніки, технологій та раціонального мислення, а від етики спілкування, етики безпеки, екологічної етики та, зрештою, етики відповідальності, де забезпечуються усі права і свободи людини, а також людська гідність та цінності особистості. За таких умов виникає теоретичний та практичний запит на пошуки відповідей щодо нових вимірів та аспектів проблеми відповідальності, формування її нового образу.

Постановка проблеми і стан іiі дослідження. Аналіз останніх публікацій показав, що подальший розвиток суспільства, людини відбувається разом із формуванням сучасних підходів до загальнолюдських цінностей. Серед робіт із цієі тематики можна виокремити дослідження таких сучасних науковців, як К.-О. Апель, Д. Бьолер, Ю. Габермас, А. Гелен, В. Гьосле, Г. Йонас, А. Єрмоленко, В. Кульман, М. Рідель.

Незважаючи на досить широкий спектр проведених досліджень, питання поглиблення філософського дискурсу відповідальності в аспекті співвідношення ії̈ особистого та колективного вимірів та людської гідності не втрачає своєї актуальності особливо за доби глобалізації, віртуалізації людського буття, що й стало предметом статті.

Метою статті є дослідження феномена відповідальності в сучасній зарубіжній філософії.

Методи дослідження, використані у процесі написання статті, передбачають застосування загальнонаукових та емпіричних прийомів, що грунтуються на системному підході. Крім цього, у процесі роботи застосовувались такі загальні методи досліджень, як узагальнення та порівняння. У результаті проведеного аналізу визначено основне коло питань, які виникають у рамках дослідження феномена відповідальності в сучасній зарубіжній філософії.

Виклад основного матеріалу. Певним рубіконом переосмислення (насамперед у сучасній європейській філософіï) питання людської гідності, рівності, свободи та відповідальності стали події Другої світової війни, коли, окрім безпосередніх військових втрат, досить велика кількість людей зазнала як фізичних, так і моральних травм, страждань та принижень. Через силове насадження ідей меншовартості серед багатьох народів Європи та світу відбувалися фізичне знищення, нелюдські тортури та поневіряння у концтаборах цілих народів, сегрегація у населення на окупованих територіях і знецінення не тільки загальнолюдських морально-етичних норм, але й самого життя. При цьому вкрай гостро постало питання відповідальності людини за свої вчинки щодо інших, адже найстрашнішим у тих подіях було те, що зазначені звірства здійснювалися на теренах високої цивілізації високоосвіченими людьми в умовах, коли така жорстокість не мала ніяких виправдань та підстав. Після закінчення жахіть війни людство надало належну оцінку тим подіям та дійшло висновків щодо питань відповідальності за ганебні вчинки та приниження людської гідності. Так, уже 10 грудня 1948 року Організацією Об'єднаних Націй було прийнято «Загальну декларацію прав людини", яка починається з таких слів: «всі люди народжуються вільними і рівними у своїй гідності та правах" [7]. Це стало поштовхом до включення в основні закони багатьох країн положень щодо цінності людської особистості та людської гідності, що накладає певний рівень відповідальності як на особистісному рівні, так і на рівні політичної, військової еліти за прийняті рішення щодо кожного громадянина своєї країни і людини загалом. Як зазначає К.-О. Апель у своїй класичній роботі «Дискурс та відповідальність», «слово «відповідальність» має одне чітке значення, де кожний отримує публічно визначені результати своєї діяльності і це знає: політик - з успіху, фабрикант - з ринку, службовець - 
з критики начальством, робітник - з контролю за наслідками своєї роботи тощо», тому «ця реакція на здогадні надмірні вимоги постконвенціональної, визначальної для всього людства етики відповідальності вельми точно ілюструє політичний вихідний пункт для дискурсивної етики сьогодні" [1, с. 405], коли співвідповідальність починає характеризуватися політичною відповідальністю усього суспільства. Для високого рівня відповідальності, окрім посадових обов'язків, людина повинна мати моральність та гідність. Ось чому питання людської гідності все більше переходить із морально-етичної площини у правову, що робить питання людської гідності суб'єктом нормативно-правових відносин, тому виконання та дотримання норм і положень переходять із морального (природного) права у юридичне. Крім того, було доопрацьовано норми права щодо злочинів проти людства для посилення відповідальності за заподіяне проти мирного населення під час військових дій, політичних репресій тощо.

Як відзначає Ю. Габермас, питання декларування людської гідності та цінності людської особистості стало «відповіддю на заподіяні нацизмом масові злочини і на масові жертви Другої світової війни» [9]. Ось чому Ю. Габермас, досліджуючи питання «концепту людської гідності та реалістичної утопії прав людини», звертає увагу на те, що «права людини вкорінені в універсальному змісті моралі», тому «за самою своєю правовою суттю вони покликані служити захисту людської гідності, що має своєю необхідною конотацією, з одного боку, самоповагу, з іншого - соціальне визнання міжнародного статусу демократичного громадянства», а «звідси - необхідна співвіднесеність з поняттям реалістичної утопії, невід'ємною метою якої є здійснення соціальної справедливості, притаманної самим інститутам демократичної конституційної держави» [9]. Підтвердженням тези про те, що людство тільки намагається дійти до абсолютного забезпечення основоположних прав, свобод та гідного життя усіх людей, є реальність, у якій присутні і військові конфлікти, і громадянські війни, і дії політичних еліт під час заходів із втримання влади. Також людство не викорінило конфлікти на національному, релігійному та культурному рівнях, у рамках яких також відбуваються утиски прав та свобод, а також незабезпечення достатніх рівнів гідності та цінності людської особистості у соціокультурних, побутових та політичних сферах.

Важливим складовим елементом дотримання високого рівня не тільки основних прав і свобод кожної людини, але й людської гідності та цінності людської особистості виступає забезпечення належного рівня соціальної справедливості щодо «нестерпних соціальних умов і маргіналізації бідних соціальних класів; нерівності жінок і чоло- віків під час вибору місця роботи; дискримінації приїжджих, а також мовних, релігійних і расових меншин» тощо [9]. Цього, на наш погляд, можна досягти лише за умови наявності відповідної політичної справедливості, коли людина-громадянин має політичні інструменти впливу на державну політику. Ось чому важливою є не тільки декларація, але й їі практична реалізація. Йдеться про можливість для людини почуватися вільною, рівною, гідною в усіх сферах суспільного та персонального буття та бути при цьому відповідальною за вчинки як на рівні адміністративного та кримінального права, так і на рівні морального (природного) права. Ю. Габермас наголошує на тому, що «гідність людини - це сейсмограф, який показує, що права - і саме права, які повинні дати громадянам політичну спільність, дозволивши їм поважати один одного як членів добровільної асоціації вільних і рівних, - що вони конститутивні для демократичного правопорядку, а тому лише забезпечення цієї категорії прав людини створює статус громадян, які як суб'єкти рівноправності правомочні претендувати на те, щоби бути шанованими в їх людську гідність» [9]. При цьому необхідно враховувати, що «права людини являють собою реалістичну утопію, оскільки вони не прикрашають більше соціально-утопічну картину колективного щастя, а укорінюють ідеальну мету справедливого суспільства в самих інститутах конституційного держави» [10]. Отже, ще рано говорити про всеохоплююче дотримання/забезпечення прав та свобод кожної окремої людини, а йдеться лише про прагнення досягнення високого рівня, особливо, коли є «протиріччя між розширенням риторики прав людини, з одного боку, i їх зловживанням як допоміжного легітимаційного знаряддя владної політики - з іншого» [9], що сьогодні існує як на внутрішньодержавному рівні, так і стосовно цілих країн.

Коли через питання організації безпеки та захисту з боку держави та/або кількох держав здійснюється наступ на базові права і свободи громадян (прикладами використання цих аргументів є боротьба з міжнародним тероризмом проти окремих громадян та цілих країн, військовою агресією та протистояння певних політичних блоків та систем), питання відповідальності влади (насамперед політичної) за зазначені дії суттєво знижується. Важливим та актуальним постає тлумачення Г. Йонасом формування етики майбутнього через евристику страху, коли «філософія моралі мусить спершу просити поради у наших страхів, а не в наших бажань, аби знати що ми насправді цінуємо», бо «нам потрібна загроза образові людини - загроза цілком специфічного характеру, - аби ми, жахаючись цього, пізнали б істинний образ людини», адже «ми лише тоді дізнаємося про те, що поставлено на карту, коли знаємо, що воно поставлено на 
карту» [8, с. 50]. Отже, питання безпеки та загострення людських страхів тільки розширюються завдяки сучасним цифровим та інформаційним технологіями, які є у владних акторів, оскільки «багато з того, що на нас може очікувати, є радше предметом страху, ніж надії» [8, с. 336].

Однак поряд зі страхами йде надія, тому Г. Йонас відзначає, що, «оскільки страх міститься у відповідальності не меншою мірою, ніж надія, оскільки він менш прозорливий, і навіть у найкращих колах має погану моральну та психологічну репутацію, ми зобов'язані вимовити ще раз слово на його захист, адже сьогодні потребуємо його більше, ніж за інших часів - коли людство, з упевненістю у позитивному поступі людської історії, вважало його слабкістю малодушних та заляканих" [8, с. 338], бо «предмет нашої відповідальності досить-таки вразливий, тож страх за нього цілком природний» [8, с. 338]. Отже, політичними акторами використовуються/експлуатуються нові образи, меми людських страхів, але етику відповідальності необхідно ототожнювати з надією у майбутнє. На жаль, сучасний етап цивілізаційного розвитку суспільства додав до традиційних засобів та інструментів, використання яких може знищити усе людство (хімічна, ядерна зброя та засоби доставки), нові, серед яких можна відзначити цифровізацію, віртуалізацію, роботизацію технологічних процесів управління, моніторингу об'єктів критичної інфраструктури (енергетика, транспорт, медицина, переробна промисловість).

Отже, швидкість та стрімкість сучасних глобальних змін вселяють певною мірою не тільки гордість за створене, але й страхи щодо того, що буде далі, адже разом зі зростанням рівня просвітництва зростає усвідомлення вже скоєного людством в усіх сферах. Висока інтенсивність господарської діяльності людини та збільшення кількості населення на планеті, коли «масштаби, а також наслідки та побічні наслідки нашої колективної діяльності, пов'язаної з наукою, індустріальною технікою і господарськими трансакціями день у день збільшуються і стають непередбачуваними для індивідів», а також «людські взаємостосунки, які належать до сучасних світових комунікацій, стали непроглядними, анонімними та незбагненними" [2, с. 404]. Загалом усе зазначене стало впливати на довкілля (перевантажувати можливості природи до саморегуляції та самовідновлення), що привело до втрати природнім середовищем рівноваги та поширення природніх катаклізмів, змін усталених природніх явищ. Це зумовило появу нового типу небезпек - екологічної та небезпеки навколишнього середовища, тобто людство підійшло до тієї межі, коли певні дії можуть привести до загибелі самої планети Земля та людства загалом, тому «парадокс сучасної ситуації, за Апелем, визначається також взає- мовідношенням науки та етики і полягає в тому, що нагальна необхідність наукового раціонального обгрунтування норм і цінностей не може бути реалізованою в межах сучасної науки, скерованої принципом «свободи від цінностей» [5, с. 27], тобто настають передумови до переосмислення феномена відповідальності, як персональної, так і колективної, на рівні усього суспільства, оскільки «вперше в історії перед людьми практично постало завдання взяти на себе спільну відповідальність за наслідки своєї діяльності в глобальному масштабі» [5, с. 25]. При цьому необхідно враховувати, що на сучасному етапі цивілізаційного розвитку суспільства відбуваються значні трансформації, в рамках яких відбувається перехід від того, коли меншість підпорядковується більшості (елементи терпимості), до того, коли рішення приймається на засадах консенсусу усіх членів суспільства на основі аргументованого діалогу/дискурсу (елементи толерантності), тому «згода, якої можна було досягти в необмеженій комунікативній спільноті, є гарантом об'єктивності й достеменності пізнання, що заступає кантівську ідею трансцендентальної свідомості взагалі» [5, с. 34].

Як справедливо зазначає А. Єрмоленко у вступі до його «Комунікативної практичної філософії, зміна парадигми новітнього філософування здійснюється шляхом переходу від «філософії свідомості» до «філософії комунікації» та від соціології, заснованої на цілераціональності, до соціальної теорії комунікативної дії, коли "діагнозом сучасної епохи» постає «втрата сенсу», «втрата орієнтації», «втрата цінностей», «що стало наслідком тотальної експансії науково-технічної цивілізації, технічного розуму в усі області людського буття», «колонізації життєвого світу» та «дегуманізації дійсності». Комунікативна етика «досліджує можливості регуманізаціі суспільного розвитку, розглядаючи себе як етику відповідальності» $[4$, c. 13,14$]$, а феномен відповідальності стає важливим елементом нового філософського дискурсу в сучасній зарубіжній філософії.

3 огляду на це «дослідження сучасного суспільства представниками комунікативного напряму в західній філософії здійснюється в термінах кризи «технічної цивілізації», таких як «забруднення навколишнього середовища», «загроза термоядерної катастрофи», «структурні протиріччя», «панування технократичних цінностей" [4, с. 14]. До того ж сучасний розвиток суспільства продукує появу нових викликів, таких як створення штучного інтелекту та широке впровадження робототехніки, штучного інтелекту та Інтернету речей у системи управління та контролю в технологічні процеси функціонування об'єктів критичної інфраструктури перш за все телекомунікаційної, транспортної, енергетичної, медичної сфер. В таких умовах рівень відповідальності тільки зростає, адже від 
однієї людини може залежати існування всієї людської цивілізації. Отже, особливого сенсу набуває започаткована К.-О. Апелем та його учнями комунікативна етика відповідальності. Йдеться про вкорінені ціннісні переорієнтації та духовно-моральне оновлення суспільства через можливість мирного, толерантного, відповідального розв'язання політичних, національних конфліктів, вирішення екологічних проблем, адже людська гідність та примус не дуже корелюються в умовах високого рівня відповідальності усіх членів суспільства перед сучасними викликами, що постають перед суспільством на глобальному рівні. Отже, саме дискурсивна етика як етика відповідальності наповнює новим змістом такі поняття, як «відповідальність», «справедливість», «свобода», «зрілість», «суверенність особистості», «обов’язок та сумління». Більш того, основні норми етики відповідальності мають набувати практичного сенсу через побутування в моральній свідомості та інституціях демократичного суспільства.

Отже, «головною проблемою нагальної сьогодні планетарної етики відповідальності $є$ те, що вона має бути здатною якось покласти край невідповідності між величезним потенціалом і поширенням технічної діяльності (Machenk nnen) i конвенціональною мораллю людини» [1, с. 410]. K.-О. Апель наголошує на тому, що «нова вимога, яка полягає в тому, що ми повинні взяти на себе відповідальність за майбутні (як наукові й технологічні, так і політичні й економічні) наслідки та побічні наслідки нашої колективної діяльності, постає як заповіт постконвенціонального та посттрадиційного типу універсалістської етики» [2, с. 417]. Так, Г. Йонас епіграфом для своєї книги «Принцип відповідальності. У пошуках етики для технологічної цивілізації» взяв такі слова: «Остаточно розкутий Прометей, якому наука надає не знані досі ще сили, а економіка - нечувані стимули, закликає до етики, щоб через добровільне підкорення їй приборкати свою могутність, аби ця могутність не обернулася для людини лихом» [8]. А. Гелен у своїх працях «Філософія інституцій» $\mathrm{i}$ «Мораль та гіпермораль» звертає увагу на те, «що ніхто не в змозі поза суспільно-інституціональною позицією, яку він посідає чи по той бік iii, чи по той бік ролі або функції, яку виконує, нести відповідальність» [2, с. 417], не тільки індивідуальну, але й, найголовніше, колективну. Певним раціональним зерном є те, що дійсно, людина може нести відповідальність тільки в певних рамках. Однак, з іншого боку, названі А. Геленом межі відповідальності можуть бути розширені на рівні комунікації «громадянин - держава», коли певний відсоток відповідальності (універсальної) покладається на політиків, які формують порядок денний, здійснюють управління державою, контроль та моніторинг за діями посадовців, від- повідальних за певний напрям робіт, адже «раціональність дії у принципі підпорядкована раціональності системи, а тому агенти діяльності не в змозі контролювати результати своєї колективної діяльності, отже, перейняти на себе відповідальність» [2, с. 417].

Дійсно, питання універсальної відповідальності є досить складним, адже її конструкція будується на основі відповідальності кожного окремого актора i, на наш погляд, є схожою на певний механізм, робота якого залежить від «кожного гвинтика», тому повинна існувати певна ієрархія акторів, які несуть певну відповідальність за закріплений за ними напрям. Це має стосуватися як виробничої і наукової ієрархії, так і політичної, де політики виступають певними акторами колективної універсальної відповідальності, якими їх наділяють виборці, а вони формують та виконують певний порядок денний. Так, Г. Йонас пропонує такі версії категоричного імперативу: «чини так, щоб наслідки твоєї діяльності узгоджувались із продовженням справжнього (echten) життя на Землі»; чи в негативній редакції: «чини так, щоб наслідки твоєї діяльності не були руйнівними для майбутньої можливості такого життя»; чи просто: «не зашкодь умовам для продовження людства на Землі» [1, с. 412]. Наведені положення виступають імперативом «онтологічно-біологічної етики, яка обгрунтовується самоствердженням буття чи еволюцією життя», яка «не в змозі обгрунтувати більше, ніж те, що життя має бути збережене» [1, с. 412], що, на наш погляд, є певним спрощенням підходу до етики відповідальності через екологічну етику, хоча питання відповідальності через бережне становлення до природи є позитивним і правильним.

Однак Г. Йонас відзначає, що, окрім наведеного, досить значне навантаження на природу та екологію відбувається через стрімке зростання кількості населення, особливо це стосується слаборозвинених країн, де питання екологічної етики, етики збереження та етики відповідальності за майбутнє нашої спільної планети поступається проблемам фізичного виживання населення, відсталим технологіям i проходження повз останніх досягнень науки та техніки. Сьогодні є території, де немає електрики, питної води та харчів. В таких умовах цим людям дуже важко пояснити основи колективної (універсальної) відповідальності в питаннях екології та навколишнього середовища. Однак, незважаючи на це, К.-О. Апель наголошує на тому, що «лише етика, яка обгрунтовується принаймні також трансцендентально-прагматичною рефлексією на основі прав і обов' язків усіх членів ідеальної комунікативної спільноти, в змозі обгрунтувати солідарність через рівноправність і співвідповідальність усіх членів ідеальної комунікативної спільноти людства» [1, с. 412]. Сьогодні перед людством постає багато 
викликів, породжених, на жаль, самою людиною, які потребують солідарної дії усіх рівноправних членів суспільства, що підпорядковується одній меті. Це вимагає не тільки рівних соціальних та політичних прав на рівні глобального суспільства. Найголовніше, це має бути наближеним до ідеального рівня, коли усі актори є відповідальними за виконання своїх прямих обов'язків як по горизонталі, так і по вертикалі, бо без відповідальності вищих акторів за дії нижчих побудувати загальну конструкцію спільної відповідальності буде важко. Однак виникає головне питання про те, як досягти високого рівня морально-етичних норм усього суспільства лише за умови природнього (морального) права, адже широке унормування на рівні адміністративного та кримінального права створює передумови появи ознак авторитаризму. Як зазначає К.-О. Апель, «розширення і підвищення причинового потенціалу людських дій homo faber може мати значення для того, щоби проілюструвати актуальну вимогу людської життєвої ситуації до розуму і сили уявлення homo sapiens щодо встановлення етики, яка регулювала б людські взаємини», тому «етику, якщо підійти до неї з функціонального погляду, певною мірою можна розглядати як компенсацію людським розумом недостатності інстинктивних стримувачів зростаючої технічної експансії [2, с. 415].

Висновки. Підсумовуючи дослідження феномена відповідальності в сучасній зарубіжній філософії, доходимо таких висновків. Події Другої світової війни виступили каталізатором для переосмислення практичного використання імперативу забезпечення не тільки прав і свобод, але й людської гідності та цінності людської особистості. 3 огляду на це відбулося переосмислення взаємодоповнення людської гідності та цінності людської особистості із відповідальністю, коли людська гідність формується через громадянську та політичну відповідальність усіх громадян та представників влади. Представників влади треба відносити до акторів верхнього рівня, які несуть відповідальність за політичні вчинки та контролюють ефективність виконання своїх посадових обов'язків акторами нижчого рівня, що загалом дає змогу вибудувати конструкцію ідеальної колективної відповідальності. До того ж за сучасних умов етика відповідальності, як і філософія загалом, окреслює шляхи для тих людських вчинків, які орієнтуються не на страх перед майбутнім, а на надію зробити його більш безпечним, людяним, справедливим.

\section{Jimepamypa}

1. Апель К.-О. Дискурсивна етика як політична етика відповідальності у ситуації сучасного світу. Комунікативна практична філософія : підручник. Київ : Лібра, 1999. С. 395-412.

2. Апель К.-О. Екологічна криза як виклик дискурсивній етиці / пер. $з$ нім. А. Срмоленко. Колуні- кативна практична філософія : підручник. Київ : Лібра, 1999. С. 413-454.

3. Апель К.-О. Обгрунтування етики відповідальності / пер. $з$ нім. Л. Ситніченко. Першоджерела колунікативної філософії. Київ : Либідь, 1996. С. 46-59.

4. Ермоленко А. Этика ответственности и социальное бытие человека (современная немецкая практическая философия). Киев : Научная мысль, 1994. 198 с.

5. Єрмоленко А. Комунікативна практична філософія : підручник. Київ : Лібра, 1999. 488 с.

6. Єрмоленко А. Категоричний імператив відповідальності Ганса Йонаса. Йонас Г. Принцип відповідальності. Київ : Лібра, 2001. С. 357-395.

7. Загальна декларація прав людини (1948) : резолюція 217 А (III) Генеральної Асамблеї ООН від 10 грудня 1948 року. URL: https://zakon.rada.gov.ua/ laws/show/995_015\#Text.

8. Йонас Г. Принцип відповідальності. У пошуках етики для технологічної цивілізації / пер. 3 нім. Київ : Лібра, 2001. 400 с.

9. Хабермас Ю. Концепт человеческого достоинства и реалистическая утопия прав человека.

10. Bloch E. Naturrecht und menschliche Würde. Fr. am M., 1960.

\section{Анотація}

Петренко М. О. Феномен відповідальності в сучасній зарубіжній філософії. - Стаття.

У рамках статті досліджено проблему відповідальності у працях провідних західних філософів та особливості її взаємозв’язку з проблемами людської гідності та цінності особистості. Послідовно переосмислено проблему людської гідності в контексті відповідальності особи та суспільства перед викликами сьогодення, які обумовлені результатами діяльності людини, часто руйнівним впливом на довкілля та екологію нашої планети. Відзначено необхідність забезпечення політичної відповідальності усіма акторами (громадянами та представниками влади). Критично реконструйовано спроби утиску прав, свободи та людської гідності у контексті нових глобальних викликів безпеці та страхів перед майбутнім. Розглянуто зростання запиту на індивідуальну та колективну (універсальну) відповідальність усіх соціальних груп на національному (державному) та глобальному рівнях, адже формування співвідповідальності можливе за умови рівних соціально-економічних умов та політичних прав. Зазначено, що побудова конструкції колективної відповідальності базується на відповідальному ставленні до своїх посадових обов'язків усіх акторів, а також створенні механізму контролю акторів з більшими повноваженнями над результатами діяльності акторів нижнього рівня. Насамперед це стосується управління об'єктами критичної інфраструктури та політичними акторами, яким делегуються не тільки влада, але й відповідальність за вчинені дії. Крім того, питання людської гідності та відповідальності тісно пов'язані у контексті громадянської відповідальності та політичної відповідальності громадян та влади. Досліджено наближення реалістичної моделі відповідальності до ідеальної, що уможливить ефективне впровадження колективної відповідальності на правах співідповідальності усіх іiі 
суб'єктів у межах створення вільного, справедливого та гідного людини соціокультурного простору.

Ключові слова: людська гідність, права та свободи, морально-етичні норми, індивідуальна, колективна, громадянська та політична відповідальності, дискурсивна етика, екологічна етика, етика відповідальності.

\section{Summary}

Petrenko $M$. O. The phenomenon of responsibility in modern foreign philosophy. - Article.

The article examines the problem of responsibility in the works of leading Western philosophers and the peculiarities of its relationship with the problems of human dignity and personal value. The problem of human dignity has been consistently rethought in the context of the responsibility of the individual and society to the challenges of today, which are due to human performance, often devastating impact on the environment and ecology of our planet. The need to ensure political accountability of all actors (citizens and government officials) was noted. Attempts to suppress rights, freedoms, and human dignity in the context of new global security challenges and fears of the future have been critically reconstructed.
The growth of demand for individual and collective (universal) responsibility of all social groups at the national (state) and global levels is considered because the formation of co-responsibility is possible under equal socio-economic conditions and political rights. It is also noted that the construction of collective responsibility is based on the responsible attitude of all actors to their job responsibilities, as well as the creation of a mechanism for controlling actors with greater authority over the performance of lower-level actors. This primarily concerns the management of critical infrastructure and political actors, to whom not only power but also responsibility for actions is delegated. In addition, issues of human dignity and responsibility are closely linked in the context of civic responsibility and the political responsibility of citizens and the authorities. The approximation of a realistic model of responsibility to the ideal, which will allow the effective implementation of collective responsibility on the rights of co-responsibility of all its subjects within the creation of a free, fair and dignified socio-cultural space.

Key words: human dignity, rights and freedoms, moral and ethical norms, individual, collective, civil and political responsibilities, discursive ethics, ecological ethics, ethics of responsibility. 